\title{
Vliv rodičovských charakteristik na výběr partnera
}

\author{
Lucie Kuncová, Zuzana Štěrbová, Jan Havliček
}

\section{Úvod}

Výběr partnera patří mezi významná životní rozhodnutí a má značný dopad na psychickou pohodu a kvalitu života (Kohler, Behrman, \& Skytthe, 2005). Kritéria výběru partnera je obecně možné rozdělit na sociodemografické (napřs. vzdělání), psychologické (např. osobnostní charakteristiky) a fyzické (např. výška postavy). Ačkoli je mezi jedinci v průměru vysoká shoda v preferencích pro určité rysy (např. symetrie), interindividuální variabilita v celkovém hodnocení přitažlivosti je značná (Havlíček, Štěrbová, \& Csajbók, v tisku). Tyto individuální preference se mohou formovat na základě charakteristik rodičů, jež mohou sloužit jako „předloha“ pro pozdější výběr partnera. Několik předchozích studií ukázalo, že lidé mají tendenci vybírat si partnera podobného svému rodiči opačného pohlaví v různých vzhledových charakteristikách, např́klad ve tváři či barvě očí a vlasů (Little, Penton-Voak, Burt, \& Perrett, 2003; pro přehled viz Štěrbová \& Havlíček, 2017). Výsledky některých studií navíc naznačují, že by podobnost mezi partnerem/kou a rodičem opačného pohlaví mohla pozitivně souviset s kvalitou vztahu s rodičem v období dětství (Bereczkei, Gyuris, \& Weisfeld, 2004). Doposud však nebyla testována podobnost mezi rodičem a partnerem/kou např́íc různými modalitami, ani dopad podobnosti na kvalitu partnerského vztahu.

Cílem této zprávy je představit výzkumný projekt „Vliv rodičovských charakteristik na výběr partnera“, který byl podpořen Grantovou agenturou ČR (GA18-15168S) a je řešený na Př́ŕrodovědecké fakultě UK. Jedná se o multioborový projekt zahrnující nejen psychologické, ale i některé biologické a chemické metody, čímž přispěje ke komplexnějšímu porozumění zkoumaného fenoménu. Hlavním cílem projektu je zjistit, zda si lidé vybírají partnery podobné svým rodičům opačného pohlaví ve tváři, tělesné vůni, hlasu, temperamentových a osobnostních charakteristikách. Zároveň jsme testovali spojitost mezi podobností partnera/ky a rodiče a kvalitou vztahu s rodičem v době dětství (do 12 let). V neposlední řadě jsme se zaměřili na otázku, zda podobnost mezi partnerem a rodičem souvisí s partnerskou a sexuální spokojeností. V př́padě tělesné vůně jsme testovali nejen vnímanou míru podobnosti, ale i podobnost $\mathrm{v}$ podpažním mikrobiomu (tělesná vůně je produktem bakteriální aktivity) a v chemickém složení pachových vzorků. Podobně u nahrávek hlasu jsme testovali podobnost jak na percepční úrovni, tak i pomocí akustické analýzy. U obličejových fotografíi jsme opět testovali percepční podobnost a tvarovou podobnost pomocí geometrické morfometrie (GMM). Níže uvádíme stručný přehled použitých metod s důrazem na celkovou představu o projektu. U metod, které nejsou v psychologii běžně využívány, jsme se snažili o jejich rámcové představení. Detaily jednotlivých postupů budou prezentovány spolu s výsledky v připravovaných odborných studiích. Metodika projektu včetně predikcí byly předregistrovány pomocí platformy Open Science Framework (https://osf.io/adrtc). 


\section{Metody}

\section{Participanti}

Studie se zúčastnilo 66 mužů (dále nazýváni cíloví participanti), jejich matek a partnerek, a 67 žen (dále nazývány cílové participantky), jejich otců a partnerů z celé České republiky. Pro účast ve studii jsme zvolili věkové omezení (cíloví/é participanti/ky a jejich partneři/ky 18-40 let, rodiče 18-65 let) kvůli možným změnám v tělesné vůni, hlasu a tváři v závislosti na věku (Mitro et al., 2012). Další podmínkou účasti bylo, že cíloví/é participanti/ky vyrůstali ve společné domácnosti s rodičem opačného pohlaví minimálně do 12 let a měli dlouhodobý vztah s partnerem/kou trvající alespoň 6 měsíců s perspektivou do budoucna. Partneři a rodiče byli nekuřáci v dobrém zdravotním stavu bez nemocí a užívání léků ovlivňujících tělesnou vůni.

\section{Procedura}

Rodiče a partneři poskytli vzorky své tělesné vůně, fotografii tváře a nahrávku hlasu. Celá triáda zároveň vyplnila sadu psychologických dotazníků. Před sběrem participanti obdrželi balíček s informovaným souhlasem, vytištěnými instrukcemi, přednastaveným mobilním telefonem a materiálem ke sběru tělesné vůně, aby mohli celý proces sběru provést samostatně.

\section{Sběr tělesné vůně}

Kvalitu tělesné vůně může ovlivnit celá řada kosmetických produktů, potravin a aktivit. Rodiče a partneři byli proto požádáni, aby se 48 hodin před sběrem tělesné vůně zdrželi konzumace vybraných aromatických jídel (např. česnek, cibule, chilli, zrající sýry), alkoholu a aktivit ovlivňujících tělesnou vůni (např. užívání kosmetiky a fyzicky náročných aktivit). Před samotným sběrem se umyli poskytnutým neparfemovaným mýdlem. Jako první si odebrali vzorky pro chemický rozbor tělesné vůně. Participanti 20x otřeli pravé a 20x levé podpaží odběrovou štětinkou, kterou umístili do uzavíratelné skleněné vialky. Obdobným způsobem probíhal i odběr vzorků axilárního mikrobiomu. Odběrovou štětinku následně uzavřeli ve zkumavce s etanolem. Nakonec si participanti pomocí bavlněných tamponků odebrali vzorek tělesné vůně. Bavlněné tamponky si nalepili do pravého i levého podpaží a oblékli si čisté $100 \%$ bavlněné triko, aby zabránili možné kontaminaci pachy z okolí. Sběr vůně probíhal přes noc po dobu 12 hodin (Havlíček et al., 2011). Po odběru byly všechny vzorky uchovávány v mrazicím boxu při $-20^{\circ} \mathrm{C}$.

\section{Fotografie tváře}

Fotografie tváŕí participanti pořídili pomocí druhé osoby vaplikaci Open Camera na poskytnutý mobilní telefon. Cílem bylo zajistit co nejstandardnější podmínky při pořizování fotografií. Každý účastník získal detailní instrukce k postupu pro fotografování. Portréty fotili na světlém pozadí ze vzdálenosti $75 \mathrm{~cm}$ za účelem minimalizace zkreslení díky rozdílné ohniskové vzdálenosti (Třebický et al., 2016). Osoba na fotografii byla nenalíčená, bez doplňků (např. náušnic, řetízků či brýlí) a zaujala neutrální výraz v obličeji. Každý z participantů byl vyfotografován dvakrát, jednou s běžným účesem a podruhé s čelenkou, aby byl vidět přechod mezi čelem a linií vlasů. Fotografie s čelenkou jsme následně využili pro morfometrickou analýzu pomocí GMM. 


\section{Nahrávka hlasu}

Nahrávky hlasů participanti stejně jako fotografie pořizovali na zapůjčený mobilní telefon (aplikace Hlasový záznamník) na základě detailních instrukcích k nahrávání. Participanti byli požádáni o vytvoření nahrávky v tiché místnosti. Telefon položili na podložku (knihu) umístěnou na desce stolu. Jejich ústa byla vzdálena $30 \mathrm{~cm}$ od telefonu. Následně běžným hlasem přečetli přiložený text sestávající se z počítání od 1 do 10 , čtení krátkých a dlouhých samohlásek, věty z běžné konverzace a představení se. Tímto způsobem jsme získali hlasové nahrávky za standardizovaných podmínek, které byly následně použity pro percepční hodnocení a akustickou analýzu.

\section{Psychologické dotazníky}

Cíloví/é participanti/ky vyplnili sadu psychologických dotazníků zaměřených na kvalitu jejich vztahu s rodiči, attachment, různé aspekty spokojenosti v partnerském vztahu, osobnost a temperament. Všechny dotazníky byly použity v české jazykové mutaci, při jejíž přípravě byla využita metoda zpětného překladu. Konkrétně se jednalo o dotazník Zapamatované rodičovské chování (s-EMBU; 23 položek, Arrindell a kol., 1999), který byl validován na slovenské populaci (Poliaková, Mojžišová, \& Hašto, 2007). Dotazník zahrnuje tři škály Emoční vřelost, Odmítavost a Hyperprotektivitu. Cíloví/é participanti/ky i rodiče dále vyplnili dotazník Zkušenosti vblízkých vztazích (The Experiences in Close Relationships Relationship Structures; ECR-RS; 9 položek, Fraley, Heffernan, \& Vicary, 2011) zkoumající současný attachment (škála Vyhýbavost a Úzkostnost) s rodičem. Oba partneři vyplnili Dotazník kvality vztahu (Relationship Assessment Scale; RAS; 7 položek; Hendrick, 1988) zkoumající partnerskou spokojenost, a Nový dotazník sexuální spokojenosti (The New Sexual Satisfaction Scale; NSSS; 20 položek; Štulhofer, Buško, \& Brouillard, 2008) zaměřený na sexuální spokojenost. Dotazník zahrnuje dvě subškály - Vlastní sexuální prožitky a Sexuální prožitky s partnerem. Celá trojice (tj. včetně rodiče) vyplnila dotazník NEO pětifaktorový osobnostní inventáŕ (NEO Five Factor Inventory; NEO-FFI; 60 položek; Costa \& McCrae, 1992; česká verze Hřebíčková \& Urbánek, 2001), který obsahuje pět škál - Př́ivětivost, Svědomitost, Neuroticismus, Extraverzi a Otevřenost. Celá trojice dále vyplnila Temperamentový dotazník emocionality, aktivity a sociability (Emotional, Activity and Sociability Temperament Survey; EAS; 20 položek; Buss \& Plomin, 1984) složený ze čtyř subškál - Aktivity, Emocionality, Sociability a Stydlivosti.

\section{Hodnocení podobnosti}

\section{Vnímaná podobnost}

Vnímanou podobnost partnera/ky a rodiče opačného pohlaví ve tváři, hlase a tělesné vůni jsme testovali pomocí metody „přiřazení podle vzoru“ (match-to-sample test). Pro hodnocení vnímané podobnosti ve tváři jsme vytvořili sady obsahující fotografii rodiče opačného pohlaví na levé straně (sloužící jako vzor) a čtyři fotografie na pravé straně - fotografii partnera/ky a fotografie tř́ jedinců stejného pohlaví ve věku partnera/ky, které jsme použili jako distraktorní. Úkolem hodnotitelek bylo seřadit čtyři fotografie napravo podle vzoru od nejvíce po nejméně podobnou. Obdobným způsobem jsme vytvořili sady vzorků tělesné vůně a hlasových nahrávek. Každá sada byla ohodnocena minimálně 20 hodnotitelkami (celkem se 
hodnocení zúčastnilo 732 žen, 18-35 let). Hodnotitelky nejdříve ohodnotily podobnost 5 sad vůní, následně pokračovaly s hodnocením 5 sad tváŕí a 5 sad hlasů. Celkem jsme uspořádali 6 kol hodnocení (celkem 32 dnů). U všech vůní, tváří a hlasů hodnotitelky zároveň ohodnotily jejich atraktivitu a maskulinitu/femininitu.

\section{Měřená podobnost}

\section{Chemická analýza}

Ke zjištění chemické podobnosti tělesné vůně partnera/ky a rodiče opačného pohlaví jsme provedli chemickou analýzu vzorků tělesné vůně prostřednictvím plynové chromatografie $(\mathrm{GC} \times \mathrm{GC} / \mathrm{TOFMS})$. Nejdř́ve jsme extrahovali látky z pachového vzorku do kapalné a následně plynné fáze bez ztráty koncentrace. Plynná forma přešla přes kolonu, kde došlo k oddělení jednotlivých složek obsažených v plynu. Ty procházely v závislosti na koncentraci v různém čase (retenční čas) přes detektor chromatografu, který výsledné koncentrace vynesl na eluční křivku. Posledním krokem byl průchod složek přes hmotnostní spektrofotometr, kde byly jednotlivé částice složek ionizovány pro zjištění jejich hmotnostního poměru. Jednotlivé ionty byly rožrazeny podle hmotnostního poměru, což umožnilo identifikaci složek obsažených ve vzorku. Průměrnou míru podobnosti partnera a rodiče (skutečná dyáda) jsme porovnali s průměrnou mírou podobnosti náhodně spárovaných dyád (všech partnerů a rodičů daného pohlaví v souboru) vzniklých pomocí permutačního testu (10 000 opakování). Tento způsob testování míry podobnosti mezi partnerem a rodičem jsme použili i v př́ípadě analýz axilárního mikrobiomu, GMM a akustické analýzy.

\section{Analýza axilárního mikrobiomu}

Tělesná vůně vzniká v důsledku metabolické aktivity kožní mikroflóry a její složení ovlivňuje výsledný tělesný pach. $Z$ tohoto důvodu jsme provedli analýzu axilárního mikrobiomu. Ze získaných axilárních stěrů jsme nejdříve izolovali metagenomickou DNA, kterou jsme namnožili pomocí polymerázové řetězové reakce (PCR). Následně jsme metodou sekvenace nové generace (high-throughput sequencing analysis) sekvenovali oblast $16 \mathrm{~S}$ rRNA. Získané genetické sekvence byly identifikovány pomocí genetických databází (RDP classifier, Wang et al., 2007; a Silva database, Quast et al., 2013). Tato procedura umožnila vytvořit mikrobiální profily partnerů a rodičů, jejichž vzájemnou podobnost jsme následně porovnali s podobností náhodně spárovaných dyád partnerů a rodičů.

\section{Geometrická morfometrie}

Pro zjištění tvarové podobnosti tváří jsme použili metodu geometrické morfometrie (GMM; Adams, Rohlf, \& Slice, 2004). GMM představuje soubor analytických metod pro mnohorozměrnou statistickou analýzu tvarové variability. Pomocí softwaru tpsDig2 bylo na každém z obličejů označeno 72 homologických bodů (např. koutky očí, úst a další) a 36 bodů znázorňující křivky. Získané konfigurace bodů jsme superponovali pomocí zobecněné Prokrustovské analýzy, což umožnilo standardizovat velikost objektů tak, aby došlo k odstranění vlivu rotace a pozice. Dále jsme provedli analýzu relativních warpů (RWA Relative Warp Analysis) pro zjištění variability v rámci konfigurace bodů u všech obličejů. 


\section{Akustická analýza}

Analýzu hlasů jsme provedli pomocí softwaru Praat (Boersma \& Weenink, 2015). K porovnání podobnosti hlasu partnera/ky a rodiče opačného pohlaví jsme porovnávali fundamentální frekvenci (výška hlasu), formanty (barva hlasu), harmonické frekvence (hlasová kvalita) a hlasitost. Dále jsme využili i další akustické proměnné charakterizující kvalitu hlasu (odvozené spektrum amplitud prvních čtyř harmonických frekvencí, spektrální sklon a první čtyři spektrální momenty) a koeficienty perturbace (např. Šebesta et al., 2017).

\section{Vliv kvality vztahu s rodičem}

Pro zjištění kvality vztahu s rodičem v době dětství jsme pomocí lineární regrese porovnávali skóry jednotlivých škál dotazníku s-EMBU s průměrnou mírou podobnosti mezi partnerem/kou a rodičem opačného pohlaví pro každou z charakteristik. Podobně tomu bylo i v př́ípadě testování vlivu attachmentu s rodičem opačného pohlaví v současnosti.

\section{Vliv podobnosti na partnerskou a sexuální spokojenost}

Vliv podobnosti mezi partnerem/kou a rodičem opačného pohlaví na partnerskou spokojenost jsme testovali lineární regresí, přičemž závislou proměnnou byly skóry dotazníků RAS a NSSS a nezávislou proměnnou tvořila míra podobnosti mezi partnerem a rodičem ve výše uvedených charakteristikách.

\section{Závěr}

Realizace výše popsaného projektu byla z několika důvodů značně náročná. Projektu se účastnily triády participantů (cílový/á participant/ka, partner/ka a rodič), přičemž ochota aktivně participovat na projektu byla obzvláště u rodičů spíše nižší. Jedním z důvodů může být skutečnost, že se výzkum neomezoval pouze na vyplnění psychologických dotazníků, ale zahrnoval i fotografování tváří, nahrávání hlasů, a především sběr vzorků tělesné vůně. Nábor participantů probíhal na území celé ČR, což bylo vzhledem k distribuci balíčků s materiálem potřebných pro sběr dat časově a logisticky náročné. Na projektu se navíc podíleli nejen výzkumníci v oboru psychologie a behaviorálních věd, ale i vědci v oborech molekulární biologie, organické chemie, morfometrie a fonetiky. Zmíněné obory používají velmi odlišné výzkumné metody a zároveň jsou často postaveny na odlišných teoretických koncepcích. Vzájemná spolupráce tak musí nutně překonávat celou řadu úskalí, která se nám dařilo překlenout díky pravidelným informačním schůzkám. Jejich cílem bylo nejen informování řešitelského týmu o postupu prací, ale zároveň vyjasňování si metodických postupů, teoretických východisek a interpretace získaných dat.

V současné době probíhá komplexní analýza získaných dat. Předběžné výsledky z percepční části studie naznačují, že partneři a rodiče si jsou podobnější než náhodně spárované dyády např́íc všemi zkoumanými charakteristikami. Zároveň míra podobnosti zřejmě není modulována kvalitou vztahu s rodičem v dětství, jak jsme predikovali. Vzhledem k značné interdisciplinaritě projektu a významu získaných zjištění plánujeme jejich publikaci v prestižních mezioborových časopisech. 
Hlavní řešitel projektu: doc. Jan Havlíček, Ph.D., Př́rodovědecká fakulta UK, e-mail: jhavlicek@natur.cuni.cz

Další členové řešitelského týmu: Mgr. Zuzana Štěrbová, Ph.D.; Mgr. Lucie Kuncová; Mgr. Robert Hanus, Ph.D.; doc. Karel Kleisner, Ph.D.; Mgr. Jakub Kreisinger, Ph.D.; Mgr. Pavlína Kyjaková; Ph.D.; Mgr. Pavel Šebesta; Mgr. Radka Bušovská; Mgr. Šimon Pokorný; Mgr. Lucie Schmiedová; Mgr. Jitka Třebická Fialová, Ph.D.; Mgr. Vít Třebický, Ph.D.

Na projektu dále spolupracovali: Mgr. Lea Takács, Ph.D.; Mgr. Kristýna Dachsová; Mgr. Kristýna Š́pková; Mgr. Kateřina Fiurašková; Mgr. Dagmar Schwambergová; Mgr. Žaneta Pátková; Mgr. Anna Fišerová; Ema Slavíková; Mgr. Lenka Kysilková.

\section{Literatura:}

Adams, D. C., Rohlf, F. J., \& Slice, D. E. (2004). Geometric morphometrics: Ten years of progress following the 'revolution'. Italian Journal of Zoology, 71(1), 5-16.

Arrindell, W. A., Sanavio, E., Aguilar, G., Sica, C., Hatzichristou, C., Eisemann, M., ... Ende, J. van der. (1999). The development of a short form of the EMBU: Its appraisal with students in Greece, Guatemala, Hungary and Italy. Personality and Individual Differences, 27(4), 613-628.

Bereczkei, T., Gyuris, P., \& Weisfeld, G. E. (2004). Sexual imprinting in human mate choice. Proceedings of the Royal Society B: Biological Sciences, 271(1544), 1129-1134.

Boersma, P., \& Weenink, D. (2015). Praat: Doing phonetics by computer (Version5.4.09).

Buss, A. H., \& Plomin, R. (1984). Temperament: Early developing personality traits. Hillsdale, NJ: Lawrence Erlbaum Associates.

Costa, P. T., \& McCrae, R. R. (1992). Normal personality assessment in clinical practice: The NEO Personality Inventory. Psychological Assessment, 4(1), 5-13.

Curran, A. M., Prada, P. A., \& Furton, K. G. (2010). The differentiation of the volatile organic signatures of individuals through SPME-GC/MS of characteristic human scent compounds. Journal of Forensic Sciences, 55(1), 50-57.

Fraley, R. C., Heffernan, M. E., Vicary, A. M., \& Brumbaugh, C. C. (2011). The experiences in close relationships - Relationship Structures Questionnaire: A method for assessing attachment orientations across relationships. Psychological Assessment, 23(3), 615.

Havlíček, J., Lenochová, P., Oberzaucher, E., Grammer, K., \& Roberts, S. C. (2011). Does length of sampling affects quality of body odor samples? Chemosensory Perception. 4, 186-194.

Havlíček, J., Štěrbová, Z. \& Csajbók, Z. (v tisku). Human mate choice. In A. Ridley, P., d'Ettorre, \& T. M. Freeberg (eds). Routledge Handbook of Comparative Psychology. Routledge.

Hendrick, S. S. (1988). Relationship assessment scale. Journal of Marriage and Family, 50, 93-98.

Hřebíčková, M., \& Urbánek, T. (2001). Big five. NEO pětifaktorový osobnostní inventář. Testcentrum, Praha.

Kohler, H. P., Behrman, J. R., \& Skytthe, A. (2005). Partner+ children= happiness? The effects of partnerships and fertility on well-being. Population and Development Review, $31(3), 407-445$. 
Little, A. C., Penton-Voak, I. S., Burt, D. M., \& Perrett, D. I. (2003). Investigating an imprinting-like phenomenon in humans partners and opposite-sex parents have similar hair and eye colour. Evolution and Human Behavior, 24(1), 43-51.

Mitro, S., Gordon, A. R., Olsson, M. J., \& Lundström, J. N. (2012). The smell of age: perception and discrimination of body odors of different ages. PloS One, 7(5), e38110.

Poliaková, M., Mojžišová, V., \& Hašto, J. (2007). Skrátený dotazník zapamätaného rodičovského správania ako výskumný a klinický nástroj. Psychiatria-PsychoterapiaPsychosomatika, 14(2-3), 79-88.

Quast C. et al. (2013) The SILVA ribosomal RNA gene database project: improved data processing and web-based tools. Nucleic Acids Res., 41, D590-D596.

Šebesta, P., Kleisner, K., Tureček, P., Kočnar, T., Akoko, R. M., Třebický, V., \& Havlíček, J. (2017). Voices of Africa: acoustic predictors of human male vocal attractiveness. Animal Behaviour, 127, 205-211.

Štěrbová, Z. \& Havlíček, J. (2017). Sexuální imprinting v komparativní perspektivě. In L. Kesner, J. Horáček, C. Höschl, F. Španiel (eds.), Mozek a jeho člověk, mysl a její nemoc. pp. 128-135. Grada.

Štulhofer, A., Buško, V., \& Brouillard, P. (2010). Development and bicultural validation of the new sexual satisfaction scale. Journal of Sex Research, 47(4), 257-268.

Třebický, V., Fialová, J., Kleisner, K. \& Havlíček, J. (2016) Focal length affects depicted shape and perception of facial images. PLoS One, 11, e0149313.

Wang, Q., Garrity, G. M., Tiedje, J. M., \& Cole, J. R. (2007). Naive Bayesian classifier for rapid assignment of rRNA sequences into the new bacterial taxonomy. Applied and Environmental Microbiology, 73(16), 5261-5267.

Kuncová, L., Štěrbová, Z., Havlíček, J. (2021). Vliv rodičovských charakteristik na výběr partnera [zpráva o projektu]. E-psychologie, 15(4), 84-90. https://doi.org/10.29364/epsy.424 